\title{
A POLICY FRAMEWORK FOR SUSTAINABLE TOURISM DEVELOPMENT BASED ON PARTICIPATORY APPROACHES: A CASE STUDY IN THE KEDUNG OMBO TOURISM AREA-INDONESIA
}

\author{
Nafiah ARIYANI* \\ Sahid University, Department of Management, Faculty of Economics, \\ South Jakarta, Indonesia, e-mail: nafiah_ariyani@usahid.ac.id
}

\author{
Akhmad FAUZI \\ IPB University, Department of Resource and Environmental Economics, \\ Faculty of Economics and Management, Bogor, Indonesia, e-mail: fauziakhmad@gmail.com
}

\begin{abstract}
Citation: Ariyani, N., \& Fauzi, A. (2022). A POLICY FRAMEWORK FOR SUSTAINABLE TOURISM DEVELOPMENT BASED ON PARTICIPATORY APPROACHES: A CASE STUDY IN THE KEDUNG OMBO TOURISM AREAINDONESIA. GeoJournal of Tourism and Geosites, 40(1), 129-135. https://doi.org/10.30892/gtg.40115-811
\end{abstract}

\begin{abstract}
This research aims to find an alternative policy framework on tourism development Kedung Ombo-Indonesia. This study uses a qualitative approach by applying Multipol analysis method. Collecting data uses a focus group discussion method. The research participants are stakeholders of the area, such as local governments, reservoir managers, forest directors, and society. The result shows that an institutional development policy supported by good governance development programs is the best policy in the integrated scenario. Meanwhile, tourism development policies supported by developing public facilities, tourism convenience, tourism interest, marketing and promotion, and service quality are the best policy in the individual scenario.
\end{abstract}

Key words: development, Kedung Ombo, policy, tourism, Multipol

$* * * * * *$

\section{INTRODUCTION}

Tourism has become a dynamic social and economic phenomenon impacting many countries and societies (Arintoko et al., 2020). Tourism is a path of progress for many countries globally and a leverage factor in preserving local culture, tradition, and custom, directly contributing to the gross domestic product and playing an active role in environmental protection (Liu et al., 2019). Furthermore, through an integrated policy, tourism generates a higher quality of job vacancy for increasing economic and social growth, and it offers a triple-win impact for countries to move towards an inclusive and resilient economy (Khan, 2020; Yanes et al., 2019; Baptista et al., 2019; Băndoi et al., 2020; Gohori and Merwe, 2020; Prandi et al., 2021). Indonesia is a rich potential natural tourism country, and the tourism sector has become a central issue playing a vital role in the Indonesian economy (Utomo et al., 2020). Tourism development in Indonesia has been proven to provide significant benefits for the national economy and accelerate the process of economic transformation to rural areas (Nugroho et al., 2018). According to the vital role of the tourism sector in various dimensions, tourism is a sector that is always encouraged by the Indonesian government (Kodir et al., 2020). However, the tourism development in several regions in Indonesia shows insignificant results and a risky unsustainable program. Without planning involving stakeholders, overlapping policies and tourism planning more emphasize on technical aspects are the causative factors. As a complex system (Baggio, 2020), tourism development requires an accurate plan supported by all stakeholders (Coburn et al., 2021; McComb et al., 2017; dos Anjos and Kennell, 2019; Joseph et al., 2021), and it should be based on a targetoriented, participative, and comprehensive strategic approach (Arbolino et al., 2020). Tourism development in Kedung Ombo in Central Java Province is an example of unsuccessful tourism development. The absence of planning, the direction of development policies, and weak coordination among stakeholders have caused the development process to run slowly and almost unsustainably (Ariyani and Fauzi, 2019). The process of development, which has been started in 1999, has only produced a few tourist spots developed by several parties where the condition of the attractions, facilities, and convenience is limited. As a result, the impact on the society around the place has not been realized (Ariyani and Umar, 2020).

Kedung Ombo is a village that has rich natural resources for tourism, such as a forest and reservoir, which is the largest reservoir in Southeast Asia (1.8 kilometers in length, 18 meters in width, 96 meters in height, consisting of 2.830 hectares of water areas and 3.746 hectares of land). This place is located in three districts which are Grobogan, Sragen, and Boyolali. In the Kedung Ombo area, the local government does not handle it alone. Still, there are strong institutions in managing the place, Indonesian State Forestry Corporations in Juwangi and Gundih and the manager of Kedung Ombo Dam. Suppose the tourism potency in Kedung Ombo is well developed; it will significantly assist the economic growth by the infrastructure improvement and local community welfare related to the expansion of job vacancies. Moreover, it will help to reduce the forest damage due to high levels of illegal logging and optimize the multifunction of

\footnotetext{
* Corresponding author
} 
the reservoir as irrigation, power plants, and a tourism place according to the target of the Kedung Ombo reservoir at the beginning of its building. Furthermore, the scarcity of tourist destinations, especially in the Grobogan and Sragen regions, is also an opportunity to develop the tourism area in the future. This research is designed to find an appropriate policy framework for tourism development in Kedung Ombo. The policy framework will be a roadmap that the development should be able to acquire the tourism potency and impact on regional economic growth. It also can reduce forest damage and protect the primary function of the reservoir. The proposed policy framework includes policy options, scenarios, and programs based on the principle of Multipol (Panagiotopoulou and Stratigea, 2014). The result of the research is expected to fill the gap in the tourism development policy in Indonesia, especially in areas involving multi-actors.

\section{LITERATURE REVIEW}

\section{Sustainable Tourism Development Concepts}

Along with the successful and inherent tourism, which has positive and negative impacts on society, economy, and environment, a sustainable issue becomes an essential topic and concept in tourism planning and development (Postma and Schmuecker, 2017). Sustainable tourism is defined as all forms, including tourism management and development activities that maintain natural, economic, and social integrity and ensure the maintenance of natural and cultural resources (Kisi, 2019). Furthermore, sustainable tourism is also a development model in which human and natural resources are united and well-coordinated with the economic, social, resource, and environmental issues (Guo et al., 2019).

Achieving sustainable tourism requires a sustainable development process involving all interested parties' planning and coordination (Panasiuk, 2020). The development goal of potential tourism is to create long-term mutually beneficial interactions between increasing community welfare, environmental sustainability, and visitor satisfaction, and inclining the integration and unity of community development around the area (Romão et al., 2017).

\section{Tourism Development Policies}

Tourism development is defined as a part of efforts to actualize the integration in the use of various tourism resources and integrate all forms of aspects outside of tourism that are directly or indirectly related to the continuity of tourism development (Lin et al., 2021). The success of tourism development highly depends on the integration of policy, planning, and management tools (Pazhuhan and Shiri, 2020). In addition, tourism planning and policy are the most significant factors determining how tourism develops and how tourism benefits and impacts are distributed (Dredge and Jamal, 2015). Planning and policies are needed as a road map to determine development direction and regulate the tourism actors for running the activities (Almeida et al., 2017; Angelevska and Rakicevik, 2012). Furthermore, effective tourism planning helps deal with the negative effect of tourism, primarily environmental and community impacts (Almeida et al., 2017) (Dunets et al., 2019). In this context, the environment of policymakers becomes a strategic element to maintain the integration of the various motives, interests, and goals of stakeholders in order to realize sustainable tourism in the future (Arbolino et al., 2020). A tourism policy is a product of a very complex process and is related to various aspects (Rizal et al., 2021). A tourism policy is a set of discourses, decisions, and practices which are promoted by the government in collaboration with either the private or social executants to achieve a variety of goals (Velasco, 2020). Additionally, a tourism policy is an intentional action beyond the level of theoretical reflection and political intentions, which are realized into a concrete action that involves the use of public resources and the responsibility of public sector stakeholders (Zielinski et al., 2020). The government has to be a central actor, yet tourism policies do not have to be promoted and implemented exclusively by the public (Velasco, 2020). Therefore, a synergy among the government, entrepreneurs, and society is needed to plan the tourism project and development (Rizal et al., 2021; Aktymbayeva et al., 2021). The development of tourism policies, plans, and strategies should ideally ensure a harmonious symbiosis with the environment, and social life of the area occurred (Liasidou, 2019). Tourism policies must be integrated with consistent actors or at least actions designed to be consistent (Koliouska and Andreopoulou, 2020).

A tourism policy includes an uncertainty associated with selecting appropriate methods for generating scenarios, identifying the indicators used to assess scenarios, evaluating scenarios to prioritize the policy formula, and assessing the impact of policy scenarios (Perveen et al., 2017). There are many factors that can be obstacles to developing the tourism area, such as lack of attractions, demands, local resilience, climate change, and political restrictions (Paunović and Jovanović, 2017). Besides, the issue is to plan a project that emphasizes more on the technical aspect which should be a political issue about regulating all tourism elements towards sustainable tourism development (Aktymbayeva et al., 2021; Rizal et al., 2021).

Planning and policies are closely interrelated in the context of tourism governance (Dredge and Jamal, 2015). Effective governance and management are vital factors in developing a sustainable tourist area (Liu et al., 2019). Tourism governance helps to explore the constituencies of tourism places and focuses on providing direction and boundaries for tourism destinations (Bichler, 2021). Furthermore, the notion of governance has complemented tourism planning, which is not enough or can be replaced by just organizing or coordinating (Volgger et al., 2018).

\section{MATERIAL AND METHODS}

This research implements the qualitative approach to map the policy options, the scenarios, and the priority programs for the tourism development in Kedung Ombo sustainably. Collecting data is conducted through the participatory approach that is focus group discussions by involving the participants and informants, which is representative of the local government of Grobogan, Boyolali, and Sragen District, dam management, forestry management, and the local community.

The data are analysed using the policy analysis method with Multipol technic (Multicriteriapolicy). Multipol is the multicriteria evaluation method to test the effectiveness of various policies and actions to the scenario, including 
determining the framework from the best options of actions, policies, and scenarios for the project (Panagiotopoulou and Stratigea, 2014; Martelo et al., 2020). The stages of implementing the participatory approach and data analysis based on the Multipole method are shown in Figure 1. The participatory stage results a series of inputs needed in the Multipole analysis method. The inputs include success criteria, alternative programs, policies and scenarios as presented in Table 1.

Table 1. Successful Criteria, Alternative Program Action, Policy and Scenario (Source: Primary Data)

\begin{tabular}{|c|c|c|c|c|c|c|c|}
\hline Criteria & Symbol & Program & Symbol & Policy & Symbol & \begin{tabular}{|c|} 
Scenario \\
\end{tabular} & Symbol \\
\hline Increasing tourist attraction & $\mathrm{C} 1$ & $\begin{array}{l}\text { Public facility building } \\
\text { program }\end{array}$ & A1 & $\begin{array}{l}\text { Tourism } \\
\text { development policy }\end{array}$ & $\mathrm{P} 1$ & $\begin{array}{l}\text { Integrated } \\
\text { development scenario }\end{array}$ & S1 \\
\hline Increasing visitor satisfaction & $\mathrm{C} 2$ & $\begin{array}{l}\text { Tourism facility } \\
\text { development program }\end{array}$ & $\mathrm{A} 2$ & $\begin{array}{l}\begin{array}{l}\text { Infrastructure } \\
\text { development policy }\end{array} \\
\end{array}$ & $\mathrm{P} 2$ & \begin{tabular}{|l|}
$\begin{array}{l}\text { Individual } \\
\text { development scenario }\end{array}$ \\
\end{tabular} & S2 \\
\hline $\begin{array}{l}\text { Increasing the economic } \\
\text { activity and entrepreuneur }\end{array}$ & C3 & $\begin{array}{l}\text { Entrepreneurship education } \\
\text { and training program }\end{array}$ & A3 & $\begin{array}{l}\text { Institutional } \\
\text { development policy }\end{array}$ & P3 & & \\
\hline $\begin{array}{l}\text { Increasing the job opportunity } \\
\text { for local community }\end{array}$ & $\mathrm{C} 4$ & $\begin{array}{l}\text { Tourism care } \\
\text { development program }\end{array}$ & A4 & $\begin{array}{l}\text { Community } \\
\text { development policy }\end{array}$ & $\mathrm{P} 4$ & & \\
\hline $\begin{array}{l}\text { Increasing the economy- } \\
\text { social relationship in } \\
\text { surrounding area }\end{array}$ & C5 & $\begin{array}{l}\text { Security, safety and } \\
\text { environmental protection } \\
\text { program }\end{array}$ & A5 & & & & \\
\hline $\begin{array}{l}\text { Developing the care } \\
\text { community towards tourism }\end{array}$ & C6 & $\begin{array}{l}\text { Good governance } \\
\text { development program }\end{array}$ & A6 & & & & \\
\hline $\begin{array}{l}\text { Decreasing the environmental } \\
\text { damage }\end{array}$ & $\mathrm{C} 7$ & $\begin{array}{l}\text { Tourist attraction } \\
\text { development program }\end{array}$ & A7 & & & & \\
\hline $\begin{array}{l}\text { Protected the main reservoir } \\
\text { function }\end{array}$ & $\mathrm{C} 8$ & \begin{tabular}{|l|} 
Service quality \\
development program
\end{tabular} & A8 & & & & \\
\hline $\begin{array}{l}\text { Increasing the local revenue } \\
\text { and forest multifunction }\end{array}$ & C9 & $\begin{array}{l}\text { Communication and } \\
\text { information technology } \\
\text { development program }\end{array}$ & A9 & & & & \\
\hline $\begin{array}{l}\text { Increased collaboration between } \\
\text { local government, Perhutani, } \\
\text { and Kedung Ombo management }\end{array}$ & C10 & $\begin{array}{l}\text { Marketing and promotion } \\
\text { development program }\end{array}$ & A10 & & & & \\
\hline
\end{tabular}

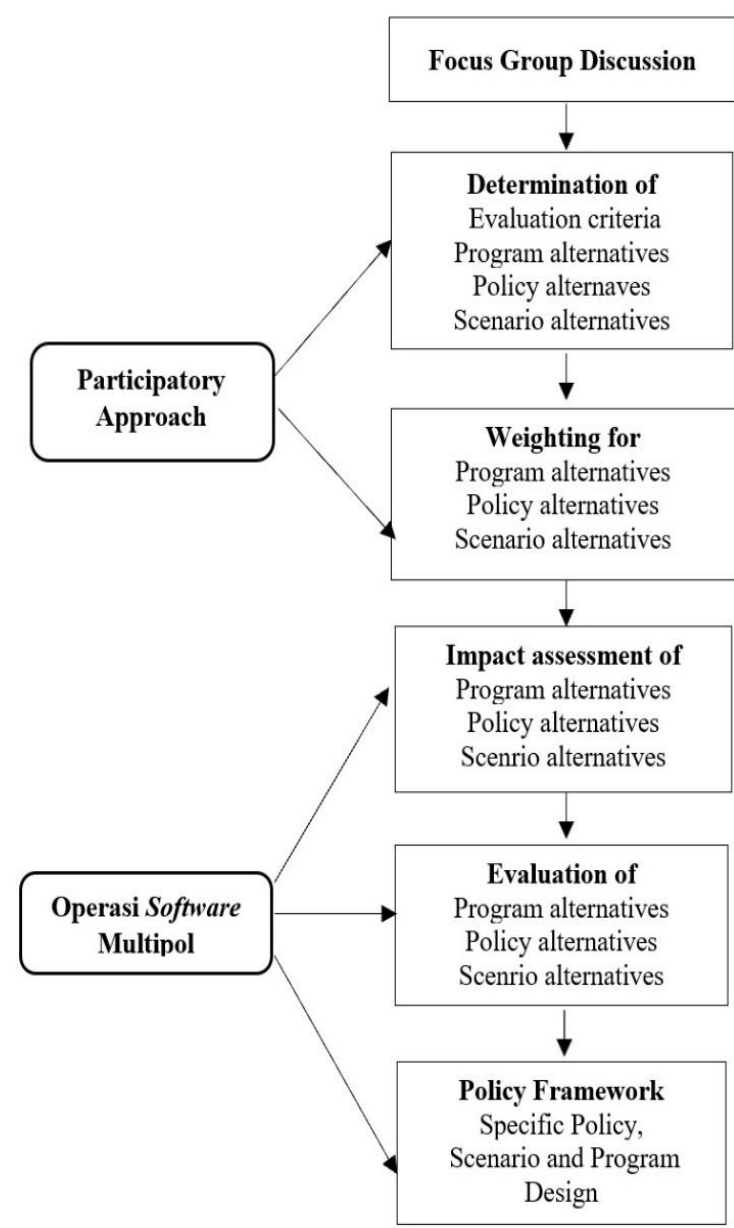

Figure 1. Stages of Determining the Policy Framework Based on the Multipole Method

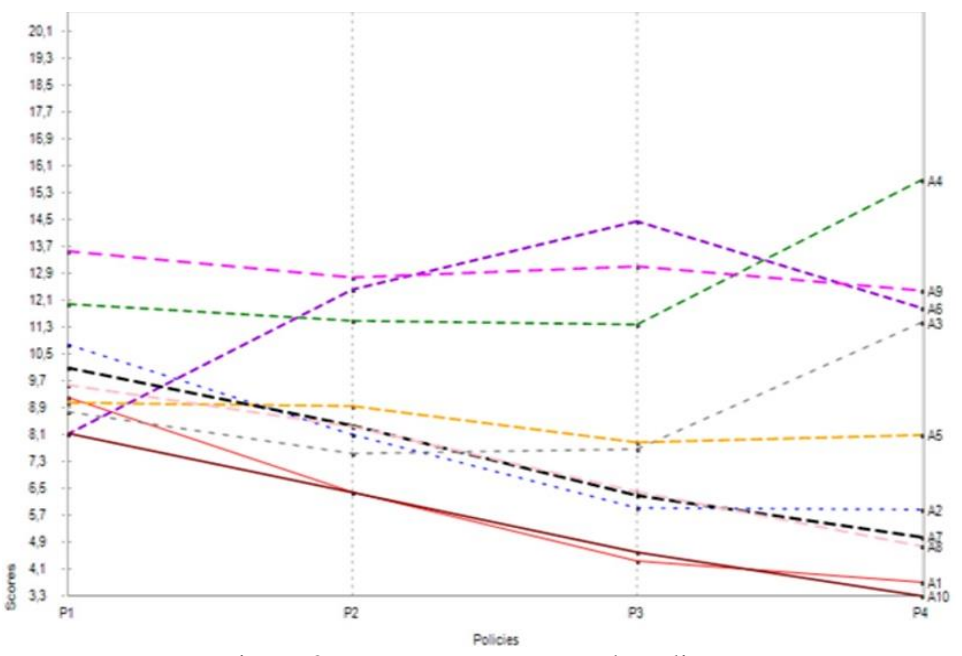

Figure 2. Program Map Towards Policy

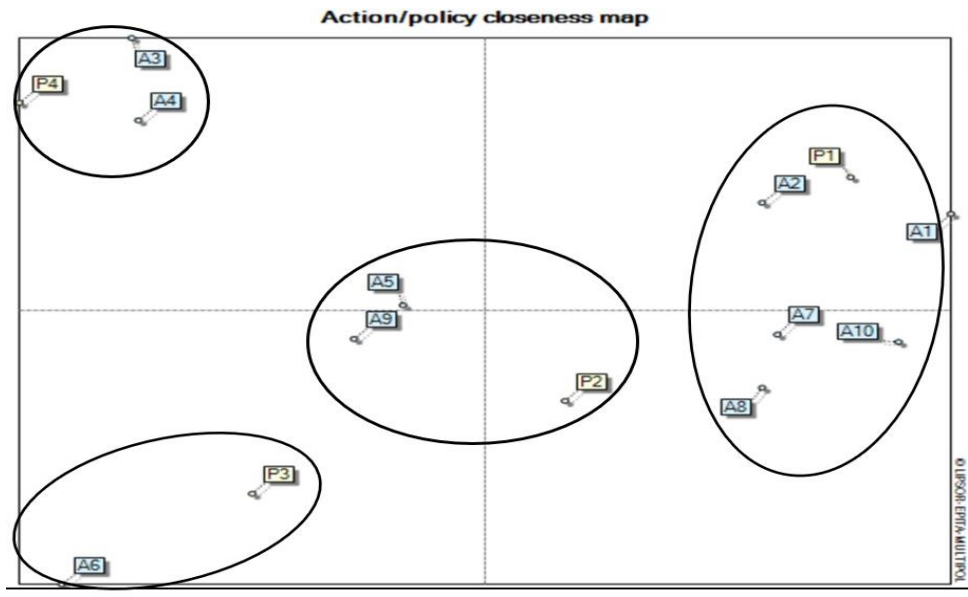

Figure 3. Closeness of Program Towards Policy 
Evaluation criteria are assessment dimensions that can be measured from the various possible options being considered that can be achieved. Evaluation criteria are the basis of any evaluation process to assess the performance of alternative scenarios, policies, and programs involved in the evaluation process. Scenarios are structured future developments in which the goals and objectives set for the system/problem at hand are achieved. Policy is a strategy to achieve the goals and objectives in planning that is closely related to the political, social, economic, and physical context in which the evaluation takes place. Meanwhile, program actions relate to potential interventions aimed at policy implementation (Panagiotopoulou and Stratigea, 2014).

\section{RESULTS AND DISCUSSIONS}

\section{Evaluation Program towards Policy}

The results of program evaluation towards the policy are shown in Table 2, showing the order of priority programs that are favoured in the tourism development of Kedung Ombo. The priority order is based on the average value and the standard deviation of each program to the policy. From Table 2, it is known the development program of communication and information technology is the most superior program. The finding is appropriate to the condition of the Kedung Ombo area, which is still very lacking in access to information technology. In contrast, the development program of marketing development and promotion is not a priority. Figure 2 is shown the featured programs of each policy. From figure 2, it can be seen that the tourism development policy (P1), the development program of communication and information technology, is the most superior program, while the marketing and promotion development programs are the least favoured. In the infrastructure development policy (P2), the communication and information technology development program is the superior program. In the institutional development policy (P3), the good governance development program (A6) is the flagship program. Meanwhile, in the community development policy (P4), the tourism care community development program (A4) is the superior program. Figure 3 shows the proximity of action programs to the policy. From Figure 3, it is known that the tourism development policy is closely related to public facilities development programs, tourism facilities development programs, tourist attraction development programs, service quality development programs, and marketing and promotion development programs. Meanwhile, infrastructure development policies are closely related to security and safety programs, and communication and information technology development programs. Meanwhile, institutional development policies are closely related to good governance development programs. Furthermore, community development policies are closely related to entrepreneurship education and training programs, and tourism care development programs. The closeness of the policy with the program can be interpreted that to implement a policy, it must be supported by closely related programs.

\section{The Policy Evaluation Towards Scenario}

The results of the policy evaluation towards the scenario, are presented in Table 3, that shows the order in which policies are favoured. The tourism development and promotion policy (P1) is the most superior policy, followed by the institutional development policy (P3) as the next leading policy. The next rank is the community development policy (P4), and the infrastructure development policy (P2) is the last leading policy. Figure 4 presents the order of policy advantages in each scenario. It is known that the institutional development policy (P3) is the most superior policy in the integrated development scenario ( $\mathrm{S} 1)$, while the community development policy (P4) is not favoured. In the individual development scenario (S2), the community development policy (P4) is the most featured, while the infrastructure development policy (P2) is not the superior policy. Figure 5 shows that the tourism development policy (P1) is a policy determinant of success in developing tourism in Kedung Ombo. This policy needs to be espoused by institutional development policies (P3) which are in the upper right quadrant, while community development and infrastructure development policies are the supporting policies.

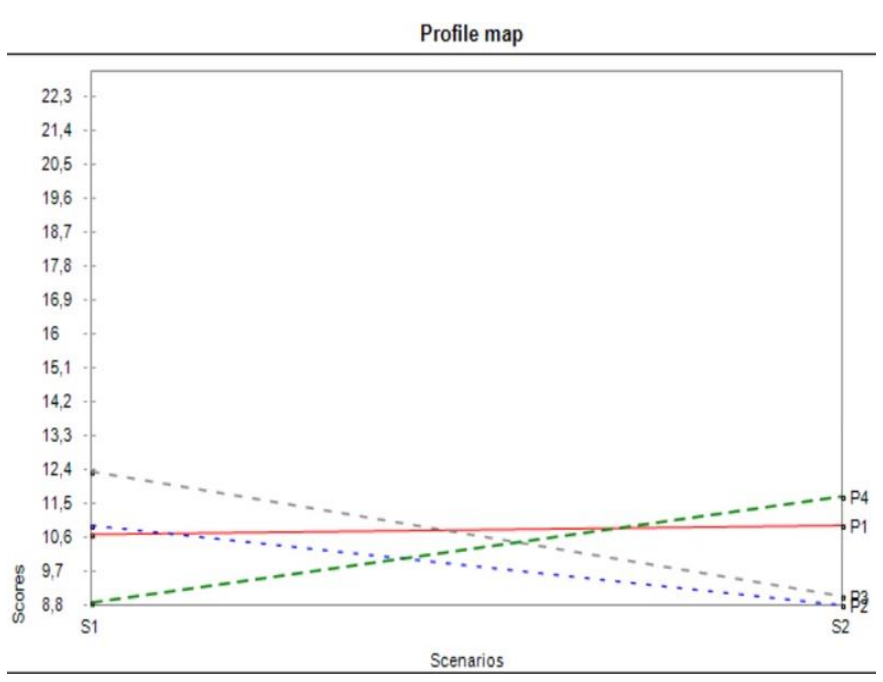

Figure 4. Priority Policy Map Towards Scenario
Table 2. Program Excellence Order (Source: The Multipol Analysis Results)

\begin{tabular}{|c|c|c|c|}
\hline Action Program/Policy & Mean & Deviation Standard & Ranking \\
\hline A1 & 6 & 2.1 & 2 \\
\hline A2 & 7.8 & 2 & 6 \\
\hline A3 & 8.8 & 1.5 & 7 \\
\hline A4 & 12.5 & 1.7 & 9 \\
\hline A5 & 8.5 & 0.5 & 6 \\
\hline A6 & 11.7 & 2.3 & 8 \\
\hline A7 & 5.3 & 0.9 & 4 \\
\hline A8 & 7.4 & 1.8 & 3 \\
\hline A9 & 13 & 0.4 & 10 \\
\hline A10 & 5.7 & 1.8 & 1 \\
\hline
\end{tabular}

Table 3. Order of Policy Excellence (Source: The Multipole Analysis Results)

\begin{tabular}{|c|c|c|c|}
\hline Policy/Scenario & Average & Deviation Standard & Ranking \\
\hline P1 & 10.8 & 0.1 & 4 \\
\hline P2 & 9.8 & 1.1 & 1 \\
\hline P3 & 10.7 & 1.7 & 3 \\
\hline P4 & 10.3 & 1.4 & 2 \\
\hline
\end{tabular}


Figure 6 shows the policy options for each scenario. In the integrated development scenario (S1), the institutional development policy (P3) and the infrastructure development policy (P2) are the superior policies, while in the individual development scenario (S2), tourism development policies and community development are the leading policies.

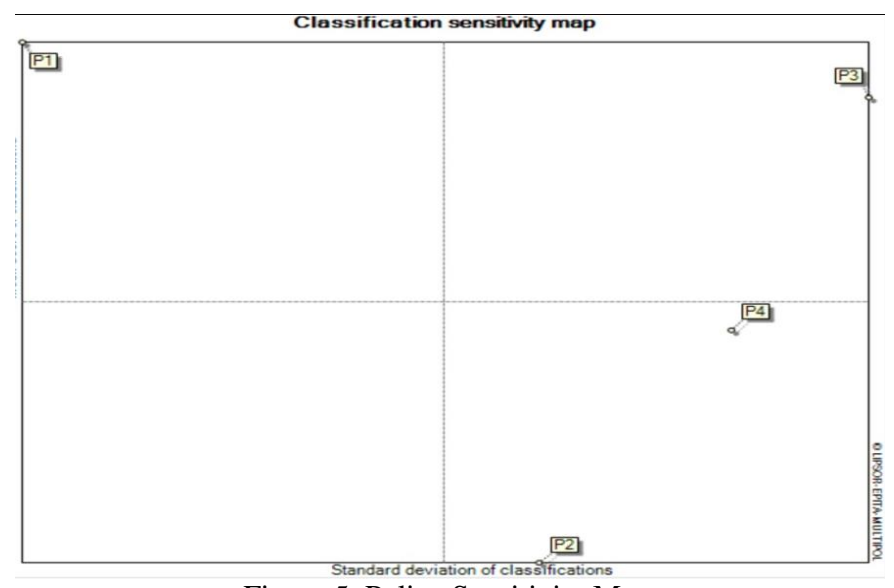

Figure 5. Policy Sensitivity Map

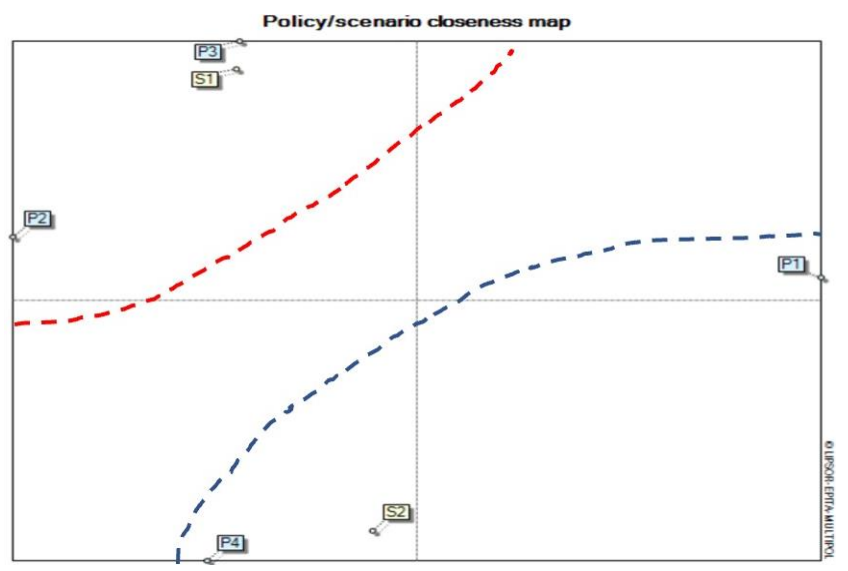

Figure 6. Policy Closeness Towards Scenario

\section{Policy Framework for Realizing Kedung Ombo Tourism}

The results of the evaluation to program, policy and scenario have been outlined, becoming the basis for determining alternative policy framework which is suitable with implemented tourism development in Kedung Ombo. This policy framework is presented in Figure 7, explaining the policy path for each scenario along with the proposed programs.
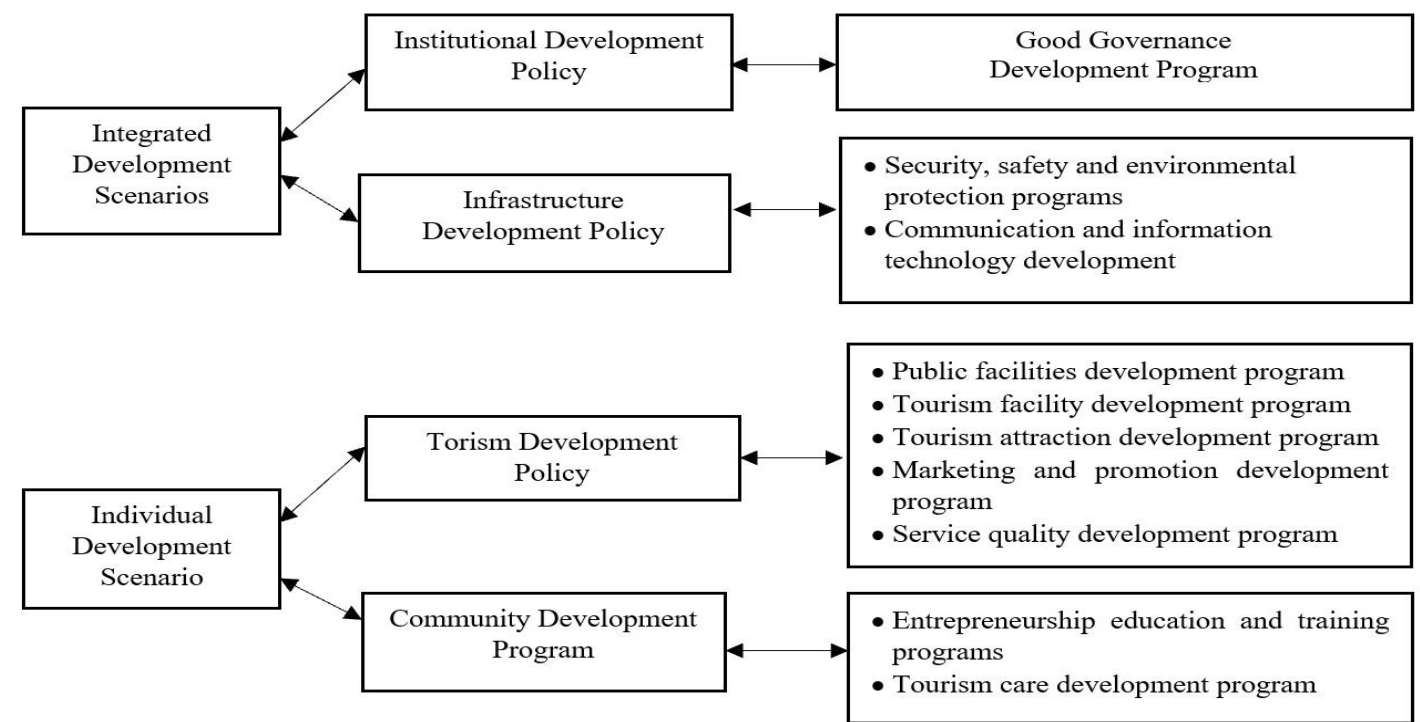

Figure 7. Potential Policy Pathways to Achieving each of the Future Scenarios of Kedung Ombo Tourism

Figure 7 explains the road map to tourism development in Kedung Ombo, started from the scenario choices, policies, and the superior programs. From the figure, it can be known to develop tourism in Kedung Ombo can be chosen two alternative development scenarios which are both integrated and individual scenarios. The integrated scenario combines all stakeholder tourism plans in the integrated system. The integrated scenario describes the collaborative work of local governments, forest and reservoir managers and communities to develop tourism in Kedung Ombo together.

This scenario emphasizes the efforts to connect between various stakeholders and resources to shape tourism multipurpose. Tourism attractions that can be developed include horse racing, agro tourism, safari parks, golf courses, cable cars to enjoy the view of the Kedung Ombo area from a height, playgrounds, and culinary delights. The integrated scenario is an appropriate alternative if it is supported by the commitment of all stakeholders.

Considering the actors freely assigns their goals and takes a strategic action to achieve the goals (Heger and Rohrbeck, 2012), the individual development scenario can be the alternative tourism development in Kedung Ombo. The individual development scenario is how Kedung Ombo tourism in the future will structurally be developed by each stakeholder separetedly. For example, each district develops their tourist destinations according to the potency of the region. This scenario is adequate relevant reminding there are so many and various interest actors in the Kedung Ombo area that have different goals and missions. As a consequence of this choice, each stakeholder must develop their capacity to provide the necessary resources to improve the infrastructure, tourism faciliti es and services, community building, and tourism workers. 


\section{CONCULSION}

The emphasis of this paper is on finding a development policy design based on a participatory planning approach in the tourism area of Kedung Ombo. The Multipole method that is used provides the solutions that facilitate the interests of several parties by presenting alternative options scenarios for tourism development along with the required policy directions for the implementation of development and program proposals. The results of the Multipole evaluation point out that the institutional development policy is the best policy in the integrated scenario. The integrated scenario is a development scenario carried out together by all stakeholders in a coordinated manner. This scenario is appropriate to Kisi's statement that one of the indicators of sustainable tourism is cross-border cooperation and stakeholder participation (Kisi, 2019). This scenario directs that all tourism locations and attractions in the Kedung Ombo area are connected. The superior program supporting this scenario is the good governance development which determines the involvement of stakeholders and regulates their respective roles based on coordination. This policy is appropriate to overcome the sectoral ego which has become prominent in a phenomenon involving many actors. In individual scenarios, each stakeholder undertakes their development of potential tourism resources.

In this scenario, tourism development policies and community policies are the leading policies. Priority programs needing to be implemented to follow this policy are programs for building public facilities, developing tourist attractions, developing marketing and promotion programs, developing service quality programs, education and training programs and developing tourism care. Considering the dynamic nature of the environment, the proposed policy framework provides the possibility of decision-making flexibility regarding unforeseen changes in the external environment in the future. Therefore, policy decisions must be prepared to be reoriented based on appropriate policy choices for each situation and environmental attribute in the future. Thus, the sustainable development of Kedung Ombo tourism will be achieved. Finally, the lessons that can be drawn from this study are related to the complex participatory processes and interactions between policies, actions and scenarios in tourism management and planning. As this study can make clear, no single policy has to do with a single program. On the other hand, a multi-policy combination and consideration of various actions or programs suit tourism development under different scenarios.

\section{Acknowledgment.}

This study was supported by the Decentralization Grants of Education and Culture Republic Indonesia Ministry in 2020. We also thank for representatives of the participants who have helped and assisted during the research.

\section{REFERENCESS}

Aktymbayeva, B., Koshkimbayeva, U., Abisheva, Z., Tokbergenova, U., \& Tumazhanova, M. (2021). Tourism industry development and governance: A comparative stage review of Kazakhstan's experience for the years of independence, 1991-2020. Geojournal of Tourism and Geosites, 34(1), 69-76. https://doi.org/10.30892/gtg.34110-621

Almeida, J., Costa, C., \& Nunes da Silva, F. (2017). A framework for conflict analysis in spatial planning for tourism. Tourism Management Perspectives, 24(July), 94-106. https://doi.org/10.1016/j.tmp.2017.07.021

Angelevska-Najdeska, K., \& Rakicevik, G. (2012). Planning of Sustainable Tourism Development. Procedia - Social and Behavioral Sciences, 44(December 2012), 210-220. https://doi.org/10.1016/j.sbspro.2012.05.022

Arbolino, R., Boffardi, R., De Simone, L., \& Ioppolo, G. (2020). The evaluation of sustainable tourism policymaking: a comparison between multicriteria and multi-objective optimisation techniques. Journal of Sustainable Tourism, 29(6), 1000-1019. https://doi.org/10.1080/09669582.2020.1843044

Arintoko, A., Ahmad, A.A., Gunawan, D.S., \& Supadi, S. (2020). Community-based tourism village development strategies: A case of Borobudur tourism village area, Indonesia. Geojournal of Tourism and Geosites, 29(2), 398-413. https://doi.org/10.30892/gtg.29202-477

Ariyani, N., \& Fauzi, A. (2019). Analysis of Strategic Variables for Ecotourism Development; an Application of Micmac. South Asian Journal of Social Studies and Economics, 3(3), 1-12. https://doi.org/10.9734/SAJSSE/2019/v3i330107

Ariyani, N., \& Umar, F. (2020). Typology of Stakeholders in Perspective of Sustainable Tourism Development Use Mactor Method. Urban Studies and Public Administration, 3(4), 20-37. https://doi.org/10.22158/uspa.v3n4p20

Baggio, R. (2020). The science of complexity in the tourism domain: a perspective article. Tourism Review, 75(1), 16-19. https://doi.org/10.1108/TR-04-2019-0115

Băndoi, A., Jianu, E., Enescu, M., Axinte, G., Tudor, S., \& Firoiu, D. (2020). The Relationship between development of tourism, quality of life and sustainable performance in EU countries. Sustainability (Switzerland), 12(4), 1-24. https://doi.org/10.3390/su12041628

Baptista, L., Pocinho, M., \& Nechita, F. (2019). Tourism and Public Policy. Series V - Economic Sciences, 12 (61)(1), 77-86. https://doi.org/10.31926/but.es.2019.12.61.1.11

Bichler, B.F. (2021). Designing tourism governance: The role of local residents. Journal of Destination Marketing and Management, 19(September 2018), 100389. https://doi.org/10.1016/j.jdmm.2019.100389

Coburn, J., Bone, F., Hopkins, M.M., Stirling, A., Mestre-Ferrandiz, J., Arapostathis, S., \& Llewelyn, M.J. (2021). Appraising research policy instrument mixes: a multicriteria mapping study in six European countries of diagnostic innovation to manage antimicrobial resistance. Research Policy, 50(4), 104140. https://doi.org/10.1016/j.respol.2020.104140

dos Anjos, F.A., \& Kennell, J. (2019). Tourism, governance and sustainable development. Sustainability (Switzerland), 11(16), 1-6. https://doi.org/10.3390/su11164257

Dredge, D., \& Jamal, T. (2015). Progress in tourism planning and policy: A post-structural perspective on knowledge production. Tourism Management, 51, 285-297. https://doi.org/10.1016/j.tourman.2015.06.002

Dunets, A.N., Vakhrushev, I.B., Sukhova, M.G., Sokolov, M.S., Utkina, K.M., \& Shichiyakh, R.A. (2019). Selection of strategic priorities for sustainable development of tourism in a mountain region: Concentration of tourist infrastructure or nature-oriented tourism. Entrepreneurship and Sustainability Issues, 7(2), 1217-1229. https://doi.org/10.9770/jesi.2019.7.2(29)

Gohori, O., \& Merwe, P. (2020). Towards a tourism and community-development framework: An African perspective. Sustainability (Switzerland), 12(13). https://doi.org/10.3390/su12135305 
Guo, Y., Jiang, J., \& Li, S. (2019). A sustainable tourism policy research review. Sustainability (Switzerland), 11(11), 1-16. https://doi.org/10.3390/su11113187

Heger, T., \& Rohrbeck, R. (2012). Technological Forecasting \& Social Change Strategic foresight for collaborative exploration of new business fields. Technological Forecasting \& Social Change, 79(5), 819-831. https://doi.org/10.1016/j.techfore.2011.11.003

Joseph, E.K., Kallarakal, T.K., Varghese, B., \& Antony, J.K. (2021). Sustainable tourism development in the backwaters of South Kerala, India: The local government perspective. Geojournal of Tourism and Geosites, 33(4), 1532-1537. https://doi.org/10.30892/gtg.334spl13-604

Khan, A., Bibi, S., Lorenzo, A., Lyu, J., \& Babar, Z.U. (2020). Tourism and development in developing economies: A policy implication perspective. Sustainability (Switzerland), 12(4), 1-19. https://doi.org/10.3390/su12041618

Kisi, N. (2019). A Strategic Approach to Sustainable Tourism Development Using the A'WOT Hybrid Method: A Case Study of Zonguldak, Turkey. Sustainability (Switzerland), 11(4). https://doi.org/10.3390/su11040964

Kodir, A., Tanjung, A., Astina, I.K., Nurwan, M.A., Nusantara, A.G., \& Ahmad, R. (2020). The dinamics of access on tourism development in Labuan Bajo, Indonesia. Geojournal of Tourism and Geosites, 29(2), 662-671. https://doi.org/10.30892/gtg.29222-497

Koliouska, C., \& Andreopoulou, Z. (2020). A multicriteria approach for assessing the impact of ICT on EU sustainable regional policy. Sustainability (Switzerland), 12(12). https://doi.org/10.3390/SU12124869

Liasidou, S. (2019). Understanding tourism policy development: a documentary analysis. Journal of Policy Research in Tourism, Leisure and Events, 11(1), 70-93. https://doi.org/10.1080/19407963.2018.1465063

Lin, H.H., Ling, Y., Lin, J.C., \& Liang, Z.F. (2021). Research on the development of religious tourism and the sustainable development of rural environment and health. International Journal of Environmental Research and Public Health, 18(5), 1-20. https://doi.org/10.3390/ijerph18052731

Liu, J., Pan, H., \& Zheng, S. (2019). Tourism Development, Environment and Policies: Differences between Domestic and International Tourists. Sustainability (Switzerland), 11(5). https://doi.org/10.3390/su11051390

Martelo, R., Fontalvo, T., \& Severiche, C. (2020). Applying MULTIPOL to Determine the Relevance of Projects in a Strategic IT Plan for an Educational Institution. Tecnura, 24(66), 76-84. https://doi.org/https://doi.org/10.14483/22487638.16176

McComb, E.J., Boyd, S., \& Boluk, K. (2017). Stakeholder collaboration: A means to the success of rural tourism destinations? A critical evaluation of the existence of stakeholder collaboration within the Mournes, Northern Ireland. Tourism and Hospitality Research, 17(3), 286-297. https://doi.org/10.1177/1467358415583738

Nugroho, I., Negara, P.D., \& Yuniar, H.R. (2018). The Planning and the Development of the Ecotourism and Tourism Village in Indonesia: a Policy Review. Journal of Socioeconomics and Development, 1(1). https://doi.org/10.31328/jsed.v1i1.532

Panagiotopoulou, M., \& Stratigea, A. (2014). A participatory methodological framework for paving alternative local tourist development paths - the case of Sterea Ellada Region. European Journal of Futures Research, 2(1). https://doi.org/10.1007/s40309-014-0044-7

Panasiuk, A. (2020). Policy of Sustainable Development of Urban Tourism. Polish Journal of Sport and Tourism, 27(2), 33-37. https://doi.org/DOI: https://doi.org/10.2478/pjst-2020-0012

Paunović, I., \& Jovanović, V. (2017). Implementation of sustainable tourism in the German Alps: A case study. Sustainability (Switzerland), 9(2). https://doi.org/10.3390/su9020226

Pazhuhan, M., \& Shiri, N. (2020). Regional tourism axes identification using GIS and TOPSIS model (Case study: Hormozgan Province, Iran). Journal of Tourism Analysis, 27(2), 119-141. https://doi.org/10.1108/JTA-06-2019-0024

Perveen, S., Kamruzzaman, M., \& Yigitcanlar, T. (2017). Developing policy scenarios for sustainable urban growth management: A Delphi approach. Sustainability (Switzerland), 9(10), 1-27. https://doi.org/10.3390/su9101787

Postma, A., \& Schmuecker, D. (2017). Understanding and overcoming negative impacts of tourism in city destinations: conceptual model and strategic framework. Journal of Tourism Futures, 3(2), 144-156. https://doi.org/10.1108/JTF-04-2017-0022

Prandi, C., Nisi, V., Ribeiro, M., \& Nunes, N. (2021). Sensing and making sense of tourism flows and urban data to foster sustainability awareness: a real-world experience. Journal of Big Data, 8(1). https://doi.org/10.1186/s40537-021-00442-w

Rizal, A., Apriliani, I.M., \& Permana, R. (2021). Sustainable management policy strategy of coastal tourism in Pangandaran district, Indonesia. Geojournal of Tourism and Geosites, 37(3), 894-904. https://doi.org/10.30892/GTG.37321-723

Romão, J., Machino, K., \& Nijkamp, P. (2017). Assessment of wellness tourism development in Hokkaido: a multicriteria and strategic choice analysis. Asia-Pacific Journal of Regional Science, 1(1), 265-290. https://doi.org/10.1007/s41685-017-0042-4

Utomo, S.H., Wulandari, D., Narmaditya, B.S., Ishak, S., Prayitno, P.H., Sahid, S., \& Qodri, L.A. (2020). Rural-based tourism and local economic development: Evidence from Indonesia. Geojournal of Tourism and Geosites, 31(3), 1161-1165. https://doi.org/10.30892/GTG.31330-553

Velasco, M. (2020). Tourism Policy. Global Encyclopedia of Public Administration, Public Policy, and Governance, (February 2017). https://doi.org/10.1007/978-3-319-31816-5

Volgger, M., Pechlaner, H., \& Pichler, S. (2018). The practice of destination governance: A comparative analysis of key dimen sions and underlying concepts, (87886). https://doi.org/http://doi.org/10.5281/zenodo.401371

Yanes, A., Zielinski, S., Cano, M.D., \& Kim, S.I. (2019). Community-based tourism in developing countries: A framework for policy evaluation. Sustainability (Switzerland), 11(9), 1-23. https://doi.org/10.3390/su11092506

Zielinski, S., Jeong, Y., Kim, S., \& B. Milanés, C. (2020). Why Community-Based Tourism and Rural Tourism in Developing and Developed Nations are Treated Differently? A Review. Sustainability, 12(15). https://doi.org/10.3390/su12155938

Article history: Received: 12.08.2021 Revised: 15.12.2021 Accepted: 11.01.2022 Available online: 01.02.2022 